\title{
The effects of severe mixed environmental pollution on human chromosomes
}

\author{
ASPASIA KATSANTONI, SHEENA NAKOU, IOANNA ANTONIADOU- \\ KOUMATOU, AND GILBERT B CÓTÉ \\ From the Institute of Child Health, GR-115 27 Athens, Greece.
}

SUMmARY Cytogenetic studies were conducted on healthy young mothers, shortly after child birth, in two residential areas each with an approximate population of 20000 , situated about $25 \mathrm{~km}$ from Athens, Greece. One of the areas, Elefsis, is subject to severe mixed industrial pollution, and the other, Koropi, is relatively free of pollution. Chromosomal aberrations were investigated in 16 women from each area in 72 hour lymphocyte cultures treated with gentian violet to enhance any chromosomal instability induced by the pollution. The women were of a comparable socioeconomic level, aged between 20 and 31 years, and with no history of factors associated with mutagenesis. Venous blood samples were taken from the two groups and processed concurrently. The slides were coded and examined independently by two observers, who were unaware of the source of the samples. A total of 100 cells was examined on each sample. The two observers obtained highly comparable results. Women from Elefsis had an average of 0.42 anomalies per cell and those from Koropi had 0.39 . The absence of a statistically significant difference between the two groups clearly shows that the severe mixed environmental pollution of Elefsis has no significant visible effect on human chromosomes in most residents. However, two Elefsis women had abnormal results and could be at risk. Their presence is not sufficient to raise significantly their group's average, but the induction by pollution of an increased rate of chromosomal anomalies in only a few people at risk could account for the known association between urban residence and cancer mortality.

The problem of population monitoring for health effects of environmental pollutants is complex especially in the case of mixed, low level chemical exposures. Chemical mutagenesis and chromosomal changes have been reported in human population groups with occupational exposure to specific chemicals, such as lead, ${ }^{12}$ vinyl chloride,${ }^{34}$ benzene, ${ }^{5}$ pesticides, ${ }^{6}$ nickel, ${ }^{7}$ and styrene. ${ }^{8}$ There has also been limited investigation of the mutagenic effects on non-occupational exposure to individual chemicals. ${ }^{9}$ Mixed exposure studies have been conducted mainly in populations residing in the vicinity of old chemical dumps ${ }^{10}$ and have been criticised for methodological faults. Excellent guidelines are available ${ }^{11-13}$ to avoid the pitfalls frequently encountered in the design and execution of such cytogenetic studies.

The gentian violet (GV) method of investigation $^{14-17}$ provides an excellent short term cyto-

Received for publication 10 July 1985 .

Accepted for publication 9 August 1985 genetic test for constitutional or induced chromosomal instability of various types. The addition of GV to lymphocyte cultures for a few hours before harvest greatly enhances chromosomal instability and raises the baseline level of anomalies, so that very small or even undetectable differences in conventional cultures become striking. Its action precludes the use of other toxic agents such as BrdU. An additional advantage of the method is that the raised baseline makes the otherwise tedious analysis of thousands of normal cells more interesting to the observer. The results are thus more reliable, especially when two observers work blindly and obtain comparable results.

\section{Areas investigated}

The polluted area in this study is centred in and around the town of Elefsis in the Thriasian Plain in Greece, bordering the south coast of Attica, about $25 \mathrm{~km}$ west of Athens. It has oil refineries, distilleries, steel mills, cement works, shipyards, and 
a large number of small industrial plants producing plastics, paints, and a wide variety of other products. The liquid waste drains into the sea, which is heavily polluted, and the various industrial processes discharge into the atmosphere fumes and particulate matter visible to the naked eye and unpleasant in smell. Climatic and geographical conditions result in frequent episodes of thermal inversion, and in the summer months the hot, dry, windy weather increases the area of dispersion of particulate matter and its inhalation by the residents.

Measurements of particulate matter in the air samples from the residential area of Elefsis ${ }^{18}$ frequently exceed the limits recommended by the World Health Organization. Between 1979 and 1981 , a survey of certain stable pollutants in the surface soil and vegetation of the Thriasian Plain showed markedly increased concentrations (two to 50 times the levels accepted as normal) of cadmium, lead, nickel, chromium, and sulphur over wide areas. ${ }^{19}$ In the immediate vicinity of Elefsis, high levels of calcium carbonate and fluoride were found, corresponding to wind dispersion from the cement works. ${ }^{20}$ It is probable that other pollutants, less amenable to measurement and possibly more toxic, are also widely dispersed throughout the residential area.

The Thriasian Plain has a total population of 40000 to 50000 , of whom about 20000 are permanent residents of the borough of Elefsis.

In 1981, the Athens Institute of Child Health started to conduct studies on the effects of the environmental pollution on the health of children in Elefsis. One of these studies was on the outcome of pregnancy, which is considered an appropriate indicator of environmental hazards. ${ }^{21}$ This study included the total pregnant population of Elefsis and, for comparison, of two smaller communities of a similar population, located in a relatively unpolluted rural area about $25 \mathrm{~km}$ east of Athens (Koropi). This study provided the opportunity for selection of two well matched populations of young women for chromosomal study, one from a heavily polluted area and one from a relatively pollution free area.

\section{Material and methods}

The populations studied consisted of 26 healthy women from Elefsis and 23 from the control area (Koropi). In each area, pregnant women were identified who were between 20 and 35 years old, non-drinkers, ${ }^{22}$ non-smokers, ${ }^{8}$ and known not to be heterozygotes for $\beta$ thalassaemia ${ }^{23}$ Women were excluded who had a history of malignancy in a first degree relative living outside the study area.
The women from both areas gave birth in the same three Athens maternity hospitals where procedure is comparable. Between two and four weeks after the women had given birth, further selection was made, excluding those women who in the previous month had taken medication other than that standard for childbirth, or had suffered a viral illness, ${ }^{24}$ or in the previous three months had undergone radiography. ${ }^{25}$ Consecutive women from each area, over the same time period, who fulfilled these conditions and agreed to participate, were included in the study.

From these women, venous blood samples were withdrawn and transported in heparinised syringes at a stable temperature. The samples were coded and the examiners were unaware of the origin of each sample.

CYTOGENETIC PROCEDURES

Upon receipt of the blood sample, conventional three day lymphocyte cultures were established in Ham's F10 supplemented with $18 \%$ fetal calf serum. GV (Merck) was added for the last three hours of incubation at a critical final concentration of $5 \mu \mathrm{g} / \mathrm{ml}$ from an aqueous stock solution of $5 \mathrm{mg} / \mathrm{ml}$ renewed every three weeks. (GV from other firms is known to require other concentrations or timing or both for the same results.) Colcemid (Gibco) $0.1 \mu \mathrm{g} / \mathrm{ml}$ medium was added during the last 90 to 120 minutes. This was followed by a 15 minute hypotonic shock in $0.075 \mathrm{~mol} / 1 \mathrm{KCl}$ and fixation in three changes of 3:1 ethanol-acetic acid for a total of one hour. Slides were air dried, stained with Giemsa, later coded by one person, and examined blind by two others. Scanning for apparently complete metaphases was done at low power and analysis at higher power under the microscope, provided that there was a total of 45 or 46 chromosomes. A few cells too difficult to analyse under the microscope were photographed and later analysed from prints. One hundred cells per subject ( 50 by each observer) were scored for breaks, gaps, deletions, chromosome rearrangements and chromatid exchanges, minutes, acentrics, monosomies, and trisomies. A square root transformation was applied to the data before the statistical analysis.

\section{Results}

Out of the 49 cultures established, 32 yielded the desired number of metaphases (16 from each group). The discarded cultures were randomly distributed among the two groups, both in number and in time, and their frequency did not significantly differ from that of parallel experiments where GV was not used. The two observers obtained highly 
comparable results, with one consistently scoring more anomalies than the other, and their overall correlation coefficient of 0.64 significantly differed from zero $(\mathrm{p}<0.01)$. Accordingly, their results were pooled and the means are shown in tables 1 and 2 .

The overall range of anomalies per cell was 0 to 18 in Elefsis women and 0 to 14 in Koropi women. Those from Elefsis had an average of 0.42 anomalies per cell (that is, $0.65 \pm 0.210$ on the transformed data) while those from Koropi had $0.39(0.63 \pm 0.163$ when transformed). Both variances $\left(F_{(15,15)}=1 \cdot 63\right.$, two tailed test, $0.2<\mathrm{p}<0.5)$ and mean $\left(t_{(30)}=0.390\right.$, one tailed test, $0.25<\mathrm{p}<0.45$ ) appeared to belong to the same population, without significant differences between the two groups.

(The same conclusion is reached when each observer's results are analysed separately, when aberra- tions implying two breakpoints (cte) are scored as two lesions instead of one anomaly, and when anomalies other than breaks and gaps are analysed separately.) The overall average for all women was 0.41 anomalies per metaphase, with a Gaussian distribution after a square root transformation. Woman No 46 from Elefsis had the only abnormal average, 1.34 anomalies per cell, more than $2 \mathrm{SD}$ from the overall population mean. She gave a second blood sample seven months later after the data were decoded. Her new level of 0.94 anomalies per cell fell within normal limits, but was still the highest of all. Woman No 44, also from Elefsis, was the only one in whom more than three cells were found to have five or more anomalies. She had five such cells with five, six, seven, eight, and 14 sporadic anomalies respectively.

TABLE 1 Characteristics of women included in study and cytogenetic results: Elefsis.

\begin{tabular}{|c|c|c|c|c|c|c|c|c|}
\hline $\begin{array}{l}\text { Subject } \\
\text { serial No }\end{array}$ & Age & $\begin{array}{l}\text { Years of } \\
\text { residence }\end{array}$ & Work outside home & $\begin{array}{l}\text { Work during } \\
\text { pregnancy }\end{array}$ & Husband's work & Father's work & cte/cell & $\begin{array}{l}\text { Total anomalies } \\
\text { per cell }\end{array}$ \\
\hline 1 & 21 & 21 & Secretary & No & Mechanic & Driver & 0.02 & 0.56 \\
\hline 4 & 29 & 21 & Shopkeeper & Yes & Postman & Farmer & 0 & $0 \cdot 25$ \\
\hline 5 & 20 & 20 & - & No & Welder & Waiter & 0 & $0 \cdot 19$ \\
\hline 9 & 28 & 5 & Plastics worker & No & Welder & Labourer & 0 & $0 \cdot 17$ \\
\hline 16 & 21 & 21 & - & No & Clerk & Café proprietor & 0.02 & $0 \cdot 27$ \\
\hline 23 & 27 & 5 & Labourer, paper factory & No & Labourer, chemical plant & - & 0 & $0 \cdot 16$ \\
\hline 27 & 20 & 20 & - & No & Driver & Sailor & 0.04 & 0.53 \\
\hline 28 & 26 & 26 & Weaver & No & Labourer, distillery & Fisherman & $0 \cdot 03$ & $0 \cdot 21$ \\
\hline 31 & 27 & 27 & - & No & Plumber & Labourer, cement works & 0.05 & 0.35 \\
\hline 36 & 20 & 20 & Clerk & No & Shopkeeper & Bargeman & 0.02 & 0.44 \\
\hline 39 & 25 & 25 & Munitions worker & No & Electrician & Operator, cement works & 0.03 & 0.77 \\
\hline 40 & 31 & 3 & Hairdresser & No & Shopkeeper & Painter & 0.02 & 0.45 \\
\hline 42 & 25 & 25 & - & No & Doctor & Farmer & 0.03 & 0.30 \\
\hline 43 & 30 & 6 & Plastics worker & No & Driver & Builder & $0 \cdot 10$ & 0.69 \\
\hline 44 & 21 & 12 & Toy factory worker & No & Driver & Shipyard worker & $0 \cdot 02$ & 0.76 \\
\hline 46 & 20 & 20 & - & No & Foreman, cement works & Taxi driver & $0 \cdot 05$ & $1 \cdot 34$ \\
\hline Mean & $24 \cdot 4$ & $17 \cdot 25$ & & & & & & 0.42 \\
\hline
\end{tabular}

TABLE 2 Characteristics of women included in study and cytogenetic results: Koropi (controls).

\begin{tabular}{|c|c|c|c|c|c|c|c|c|}
\hline $\begin{array}{l}\text { Subject } \\
\text { serial No }\end{array}$ & Age & $\begin{array}{l}\text { Years of } \\
\text { residence }\end{array}$ & Work outside home & $\begin{array}{l}\text { Work during } \\
\text { pregnancy }\end{array}$ & Husband's work & Father's work & cte/cell & $\begin{array}{l}\text { Total anomalies } \\
\text { per cell }\end{array}$ \\
\hline 3 & 22 & 22 & - & No & Builder & Farmer & 0.01 & 0.20 \\
\hline 7 & 31 & 31 & $\overline{\text { Clerk }}$ & Yes & Farmer & Gun repairer & 0.01 & 0.34 \\
\hline 8 & 26 & 26 & Accountant & Yes & Teacher & Farmer & 0.02 & 0.15 \\
\hline 13 & 20 & 20 & Salesgirl & No & Machine operator & Builder & 0 & $0 \cdot 14$ \\
\hline 17 & 21 & 3 & Weaver & No & Welder & Farmer & 0 & 0.34 \\
\hline 18 & 28 & 28 & - & No & Driver & Drill operator & 0 & 0.66 \\
\hline 21 & 21 & 3 & Cannery worker & Yes & Furniture worker & Café proprietor & 0 & 0.39 \\
\hline 29 & 28 & 4 & Furniture worker & No & Painter & Farmer & 0 & 0.21 \\
\hline 30 & 29 & 29 & Waitress & No & Cafeteria owner & Metal worker & $0 \cdot 02$ & 0.38 \\
\hline 35 & 26 & 26 & Clerk & No & Tile worker & Farmer & 0.005 & 0.44 \\
\hline 37 & 25 & 25 & Clerk & Yes & Clerk & Driver & 0 & 0.30 \\
\hline 38 & 26 & 26 & Teacher & Yes & Bank clerk & Farmer & 0.06 & 0.67 \\
\hline 41 & 25 & 25 & - & No & Printer & Teacher & 0.04 & 0.50 \\
\hline 45 & 23 & 23 & Seamstress & No & Builder & Farmer & 0.05 & 0.49 \\
\hline 48 & 28 & 28 & Teacher & No & Clerk & Driver & 0.06 & 0.94 \\
\hline 49 & 31 & 3 & Nurse & Yes & Farmer & Farmer & 0 & 0.50 \\
\hline Mean & $25 \cdot 6$ & $20 \cdot 1$ & & & & & & 0.39 \\
\hline
\end{tabular}




\section{Discussion}

The greatest possible attention was given to the experimental design in order to obtain simultaneous matched controls, to minimise possible biological and technical confounding factors, and to assure absolutely blind examination and thereby avoid unpleasant episodes of social and political character. ${ }^{13}$

The results clearly show that the severe mixed environmental pollution of Elefsis has no significant visible effect on human chromosomes in most residents. The findings of an abnormally high average of anomalies in woman No 46 and of an excess of very abnormal cells in woman No 44 may constitute the chance discovery of two subjects at risk. Their presence is not statistically sufficient to alter significantly their group's average, but it is consistent with the view that a polluted environment is more harmful to them than to the others. It has been suggested that a substantial part of the known association between urban residence and cancer mortality ${ }^{26}$ can indeed be accounted for by the presence of heterozygotes for cancer predisposing genes, who are more susceptible to pollution effects than the rest of the population. ${ }^{27} 28$

This project was originally funded by the Ministry of Social Services and later the Ministry of Health and Welfare of Greece. The authors wish to thank Professor D G Harnden for his helpful and constructive comments, criticism, and interest in this work. We also thank Alexandra Noussis for expert technical assistance.

\section{References}

${ }^{1}$ Nordenson I, Beckman G, Beckman L, Nordstrom S. Occupational and environmental risks in and around a smelter in northern Sweden. IV. Chromosomal aberrations in workers exposed to lead. Hereditas 1978;88:263-7.

2 Forni A, Sciame A, Bertazzi PA, Alesio L. Chromosome and biochemical studies in women occupationally exposed to lead. Arch Environ Health 1980;35:139-44.

${ }^{3}$ Ducatman A, Hirschhorn K, Selikoff IJ. Vinyl chloride exposure and human chromosome aberrations. Mutat Res 1975;31:163-8.

4 Czeizel A. Genetic study on polyvinyl chloride workers. Mutat Res 1977;46:215-6.

5 Watanabe T, Endo A, Kato Y, et al. Cytogenetics and cytokinetics of cultured lymphocytes from benzene-exposed workers. Int Arch Occup Environ Health 1980;46:31-41.

${ }^{6}$ Nicholas AH, Van den Berghe H. Sister chromatid exchange and pesticides with emphasis on organophosphates. In: Sandberg AA, ed. Sister chromatid exchange. Chap 20. New York: Liss, 1982:327-54.

7 Waksvik H, Boysen M. Cytogenetic analyses of lymphocytes from nickel refinery workers. Mutat Res 1982;103:185-90.

8 Watanabe T, Endo A, Kumai M, Ikeda M. Chromosome aberrations and sister chromatid exchanges in styrene-exposed workers with reference to their smoking habits. Environ Mutagenesis 1983;5:299-309.

9 Infante PF. Oncogenic and mutagenic risks in communities with polyvinyl chloride production facilities. Ann NY Acad Sci 1976;271:49-57.

10 Heath CW. Epidemiology of dump exposures. In: Chemical and radiation hazards to children. Columbus, Ohio: Ross Laboratories, 1982:10-7.

11 Bloom AD. Guidelines for the studies of human populations exposed to mutagenic and reproductive hazards. New York: March of Dimes, Birth Defects Foundation, 1981.

12 Hook EB. Human teratogenic and mutagenic markers in monitoring about point sources of pollution. Environ Res 1981;25:178-203.

13 Hook EB. ICPEMC working paper 5/2. Perspectives in mutation epidemiology. 2. Epidemiologic and design aspects of studies of somatic chromosome breakage and sister-chromatid exchange. Mutat Res 1982;99:373-82.

$14 \mathrm{Au} \mathrm{W}$, Pathak S, Collie CJ, Hsu TC. Cytogenetic toxicity of gentian violet and crystal violet on mammalian cells in vitro. Mutat Res 1978;58:269-76.

15 Au W, Butler, MA, Bloom SE, Matney TS. Further study of the genetic toxicity of gentian violet. Mutat Res 1979;66:103-12.

16 Ledbetter DH, Riccardi VM, Au WW, et al. Ring chromosome 15: phenotype, Ag-NOR analysis, secondary aneuploidy, and associated chromosome instability. Cytogenet Cell Genet 1980;27:111-22.

17 Hsu TC, Au WW, Strong LC, Johnston DA. A short-term cytogenetic test for genetic instability in humans. In: Stich HF, San RHC, eds. Short term tests for chemical carcinogens. Chap 19. Heidelberg: Springer-Verlag, 1981:217-35.

18 PERPA. Athens Environmental Pollution Control Programme. Technical report. Vol IV. Atmospheric pollution. Athens: Greek Ministry of Social Services, 1980:248-57.

19 Nakos G. Pollution of soil and vegetation in the Thriasian Plain, Greece. Plant and Soil 1982;66:271-7.

20 Nakos G. Pollution of soil and vegetation in the Thriasian Plain. I. The Elefsis area. Dasiki Erevna 1980;2:173-208 (in Greek, English summary).

21 World Health Organization. Epidemiological surveillance of environmental hazards. Report of a WHO Working Group. Copenhagen: WHO, 1981.

22 Butler MG, Sanger WG, Veomett GE. Increased frequency of sister-chromatid exchanges in alcoholics. Mutat Res 1981;85: $71-6$.

${ }^{23}$ Côté GB, Papadakou-Lagoyanni S. $\beta$-thalassaemia: increased chromosomal anomalies in lymphocyte cultures. $J$ Med Genet 1979;16:52-5.

${ }^{24}$ Nichols WW. Virus-induced chromosome abnormalities. Annu Rev Microbiol 1970;11:479-99.

25 Harnden DG. Cytogenetics of human neoplasia. In: Mulvihill JJ, Miller RW, Fraumeni JF, eds. Genetics of human cancer. New York: Raven Press. 1977:87-104.

${ }^{26}$ Ford AB, Bialik O. Air-pollution and urban factors in relation to cancer mortality. Arch Environ Health 1980;35:350-9.

27 Strong LC. Genetic-environment interactions in human cancer. In: Arrighi FE, Rao PN, Stubblefield E, eds. Genes, chromosomes, and neoplasia. New York: Raven Press, 1981:463-75.

${ }^{28}$ Evans HJ. Genes, chromosomes and neoplasia: an overview. In: Arrighi FE, Rao PN, Stubblefield E, eds. Genes, chromosomes, and neoplasia. New York: Raven Press 1981:511-25.

Correspondence and requests for reprints to Dr G B Côté, Institute of Child Health, GR-115 27 Athens, Greece. 